\title{
Bacterivorous nematodes stimulate microbial growth and exopolymer production in marine sediment microcosms
}

\author{
Cédric Hubas ${ }^{1, *}$, Calaivany Sachidhanandam ${ }^{1}$, Hervé Rybarczyk $^{1}$, \\ Helen V. Lubarsky ${ }^{2}$, Annelien Rigaux ${ }^{3}$, Tom Moens ${ }^{3}$, David M. Paterson ${ }^{2}$ \\ ${ }^{1}$ Muséum National d'Histoire Naturelle, UMR BOREA 7208 MNHN/CNRS/IRD/UPMC, CP 53, 61 rue Buffon, \\ 75231 Paris Cedex 5, France \\ ${ }^{2}$ Sediment Ecology Research Group, Scottish Oceans Institute, University of St Andrews, East Sands, \\ St Andrews, KY16 8LB, Fife, UK \\ ${ }^{3}$ Marine Biology Section, Biology Department, Ghent University, Krijgslaan 281 (S8), 9000 Gent, Belgium
}

\begin{abstract}
The cohesive strength of intertidal soft sediments depends on a large range of physicochemical parameters, but the production of exopolymers by the inhabiting organisms is increasingly recognized as a major stabilizing factor. It is likely that the vast majority of these polymers are produced by microorganisms but very few studies have addressed the impact of benthic meiofauna on this microbial production. The major aim of this study was thus to estimate the impact of nematodes (often the main contributor to meiofauna abundance and biomass in temperate intertidal habitats) on the EPS (extracellular polymeric substances) production of marine sediments. Bacterivorous nematodes Diplolaimelloides meyli Timm, 1961 and D. oschei Meyl, 1954, bacteria and diatoms were grown in laboratory experiments both separately and together to estimate their respective influence. Our experiment revealed a positive impact of bacterivorous nematodes on microbial density and EPS production. Surprisingly, the biofilm structure (in terms of microbial abundance/biomass and EPS content) was better explained by the complexity (i.e. the number of trophic levels) of the assemblages rather than by any specific types of organisms involved in the experiment.
\end{abstract}

KEY WORDS: Free living nematodes - Extracellular polymeric substances · EPS · Bacteria · Benthic diatoms $\cdot$ Marine sediment $\cdot$ Intertidal

\section{INTRODUCTION}

In intertidal habitats, the cohesive strength of sediments depends on their physicochemical properties such as water content, density, mineralogy, plasticity, salinity and $\mathrm{pH}$ (Dade et al. 1992). In addition, these habitats are colonized by different types of microorganisms which play a significant role as ecosystem engineers by stabilising the sediments (Miller et al. 1996, Stal 2010) through the production of extracellular polymeric substances (EPS) (Decho 1990, Underwood et al. 1995).

Exopolymers are a ubiquitous component of marine ecosystems primarily composed of carbohydrates, pro- teins (Decho 1990), and lipids. They have multiple roles in aquatic systems: attachment of bacteria to substrata, flotation and locomotion of diatoms, feeding, protection against desiccation/UV/pollution, development of biofilms, and communication between microorganisms (see reviews by Decho 1990, Wotton 2004 for more details). For instance, in the surface layer of intertidal sediments, benthic epipelic diatoms show an endogenous migration pattern which is achieved by the secretion of highly hydrated carbohydrate-rich exopolymers (Smith \& Underwood 1998). The properties and behaviour of intertidal marine sediments can thus not be studied without taking into account these complex substances (Stal 2010), mainly because they 
enhance the cohesion of sediments and their capacity to resist erosion, which is an important feature in habitats generally constrained by strong physical and geochemical gradients such as marine sediments.

Whilst the majority of studies have focused on microbial EPS production (with a particular emphasis on benthic diatoms and cyanobacteria), few studies have addressed the impact of benthic fauna. Notably, the effect of meiofauna on the stability of intertidal sediments has seldom been studied. Meiofauna and macrofauna can also secrete important amounts of exopolymers which coagulate sediment particles (Riemann \& Schrage 1978) and therefore may enhance sediment stability. However, they may also destabilize sediments by bioturbation (Hansen \& Kristensen 1997, de Deckere et al. 2001) and their feeding activity, either by grazing directly on the microbial EPS producers (Riera et al. 1996, Hagerthey et al. 2002) or by using the exopolymers themselves as a food source (Decho 1990, Smith \& Underwood 1998).

The biological, physical and chemical properties of the sediment and the inhabiting benthic fauna are often so inextricably interwoven in natural environments (Chapman \& Tolhurst 2007) that it renders the assessment and generalization of any relationships between them difficult. We thus decided to use laboratory microcosm experiments in which we raised bacteria, microalgae and nematodes both separately and together in order to estimate their respective influence on EPS production. Nematodes were chosen because they generally dominate soft-sediment meiofaunal communities. Two congeneric species of bacterivorous nematodes Diplolaimelloides meyli Timm, 1961 and D. oschei Meyl, 1954 were used in our experiment. Our hypothesis was that bacterivorous nematodes would impact the bacterial and microalgal growth and EPS production in marine sediments.

\section{MATERIALS AND METHODS}

Bacterial culture. Muddy intertidal marine sediment (upper 1 to $2 \mathrm{~cm}$ ) was sampled in a tidal estuary during low tide (Dourduff River, France, 48 $37^{\prime} 42.82^{\prime \prime} N$, $\left.3^{\circ} 50^{\prime} 38.81^{\prime \prime} \mathrm{W}\right)$. The sediment was mixed with an approximately equal volume of filtered $(0.2 \mu \mathrm{m})$ seawater. The resulting slurry was placed in a sonication bath (Fisher Scientific, ultrasound frequency $37 \mathrm{kHz}$ ) for $10 \mathrm{~min}$ and centrifuged twice $(6000 \times g, 10 \mathrm{~min})$ to remove most of the sediment particles. The pellets were discarded and the supernatants were mixed together and centrifuged for $10 \mathrm{~min}$ at $17000 \times \mathrm{g}$. The majority of the supernatant was discarded and the pellet containing the bacteria was resuspended in filtered seawater. The sample was then filtered (using $1.6 \mu \mathrm{m}$
Whatman GF/A filters) to separate bacteria from benthic microalgae and sediment particles. The sample which passed through the filter was mixed with a culture medium (autoclaved nutrient broth $\mathrm{N}^{\circ} 3$, Fluka BioChemika, 1:3 v/v). The culture was grown for several days at room temperature (fresh nutrients were added regularly).

Diatom culture. Because isolation and maintenance of microphytobenthic assemblages proved difficult, we decided to select an axenic culture of a single benthic diatom strain, Navicula incerta (Scottish Association for Marine Science SAMS, CCAP 1050/10). The culture was maintained using Guillard F/2 medium completed with silicate. The strain was originally isolated from a marine tidal habitat (North Carolina, USA). Cells of the genus Navicula sp. are amongst the most abundant and diverse benthic diatoms of intertidal soft sediments (MacIntyre et al. 1996, Sundbäck et al. 2000).

Nematode culture and extraction. Bacterivorous nematodes Diplolaimelloides meyli and D. oschei were obtained from monospecific laboratory cultures at the Marine Biology Laboratory, Ghent University. They originated from the Westerschelde Estuary (SW Netherlands). These species, belonging to the family Monhysteridae, are opportunistic colonizers of various types of decaying organic matter, where they feed largely on bacteria. The nematodes are grown on agar media with unidentified bacteria from their natural habitat as a food source (Moens \& Vincx 1998). Each species had been in permanent culture under identical temperature $\left(17^{\circ} \mathrm{C}\right)$ and salinity $(25 \%)$ conditions for many generations prior to the start of our experiment. The nematodes were then extracted from the culture plates using a density centrifugation in sucrose (final concentration of $40 \%$ ) and carefully washed several times with artificial seawater (Moens \& Vincx 1998).

Experimental design. Microbes (bacteria and diatoms) and nematodes were grown both separately and together on non-cohesive acid washed marine sand (40 to $100 \mu \mathrm{m}$, Fisher Scientific). A control group (C) and 7 different treatments $(\mathrm{B}, \mathrm{D}, \mathrm{BD}, \mathrm{N}, \mathrm{BN}, \mathrm{DN}$, and $\mathrm{BDN})$ were tested, each in 3 replicate microcosms incubated under the same conditions (a total of 24 boxes, $12 \times 12 \times 6 \mathrm{~cm}$ ). Treatment names refer to the first letter(s) of the corresponding culture(s) inoculated: $\mathrm{B}$ for bacteria, $\mathrm{D}$ for diatoms and $\mathrm{N}$ for nematodes. For all the boxes, a layer of about $3 \mathrm{~cm}$ of sediment was moistened with ca. $200 \mathrm{ml}$ of autoclaved seawater. Approximately $20 \mathrm{ml}$ of the bacterial and diatom cultures were added to each box of the corresponding treatments. All the nematodes extracted from the cultures were resuspended in artificial seawater and distributed equally in the corresponding boxes (Fig. 1). The nematode density in the corre- 
sponding treatments was about 4 nematodes $\mathrm{cm}^{-2}$ which was low compared to natural sediments (Heip et al. 1985).

For treatments $\mathrm{C}$ and $\mathrm{N}$, an antibiotic cocktail (streptomycin and chloroamphenicol in final concentrations of 150 and $20 \mathrm{mg} \mathrm{l}^{-1}$, respectively) was added to limit bacterial proliferation (Lee 1993). Treatments D and DN were supplemented with $150 \mathrm{mg} \mathrm{l}^{-1}$ streptomycin only (non lethal for Bacillariophyceae, Berland \& Maestrini 1969) to avoid bacterial proliferation. Chloroamphenicol was not added to those treatments as it appeared toxic to benthic diatoms (H. V. Lubarsky pers. obs.). All the treatments were oxygenated, placed at room temperature $\left(18\right.$ to $21^{\circ} \mathrm{C}$ ) and subjected to a daily $10 \mathrm{~h}$ photoperiod throughout the experiment (at a saturating irradiance of about $200 \mu \mathrm{mol}$ photons $\mathrm{m}^{-2}$ $\mathrm{s}^{-1}$, PAR 400 to $700 \mathrm{~nm}$ ).

Sampling strategy. The microorganisms (bacteria and diatoms) were added at the beginning of the experiment (Fig. 1, $\mathrm{T}_{0}$ ) to allow biofilm growth. Sediment cores were sampled 4 d later (Fig. 1, $\mathrm{T}_{1}$ ) using a cut-off syringe $\left(0.8 \mathrm{~cm}^{2}, 0.2 \mathrm{~cm}\right.$ depth). In all the boxes, 4 cores were sampled to measure, respectively, bacterial cell number, chlorophyll a concentration, EPS concentrations (proteins and carbohydrates) and total lipid concentration. The sampling was immediately followed by the addition of nematodes in the corresponding treatments. The experiment was maintained for 6 further days (10 d after $\mathrm{T}_{0}$ ) after which sediment cores were sampled again as described above (Fig. 1, $\mathrm{T}_{2}$ ). All the sediment cores were immediately frozen with liquid nitrogen after sampling and stored at $-24^{\circ} \mathrm{C}$ until analysis.

Bacterial cell number. Sediment cores were preserved with a glutaraldehyde solution (1\% final concentration). The samples were then stained with Syto13 (Molecular Probes, 1:2000 v/v, $1.2 \mu \mathrm{mol} \mathrm{l^{-1 }}$ final concentration), left for about $15 \mathrm{~min}$ in the dark, and measured with a flow cytometer (Becton Dickinson FACScan $^{\mathrm{TM}}$ with a laser emitting at $488 \mathrm{~nm}$ ). The flow rate was fixed to $12 \mu \mathrm{min}^{-1}$ and the data were recorded until 10000 events were acquired and/or after $60 \mathrm{~s}$ of counting. An internal standard was added to some samples (PeakFlow $^{\mathrm{TM}}$ reference beads $6 \mu \mathrm{m}$, $515 \mathrm{~nm}$, Molecular probes) to distinguish bacterial cells from debris and mineral particles. Bacteria were then detected, isolated from debris and counted using 'Cellquest' software by plotting the side light scatter (SSC) versus green fluorescence (FL1). Most of the measured rates were in the range of 200 events $\mathrm{s}^{-1}$ or lower. The bacterial abundance was calculated by multiplying the acquisition rates by the flow rate.

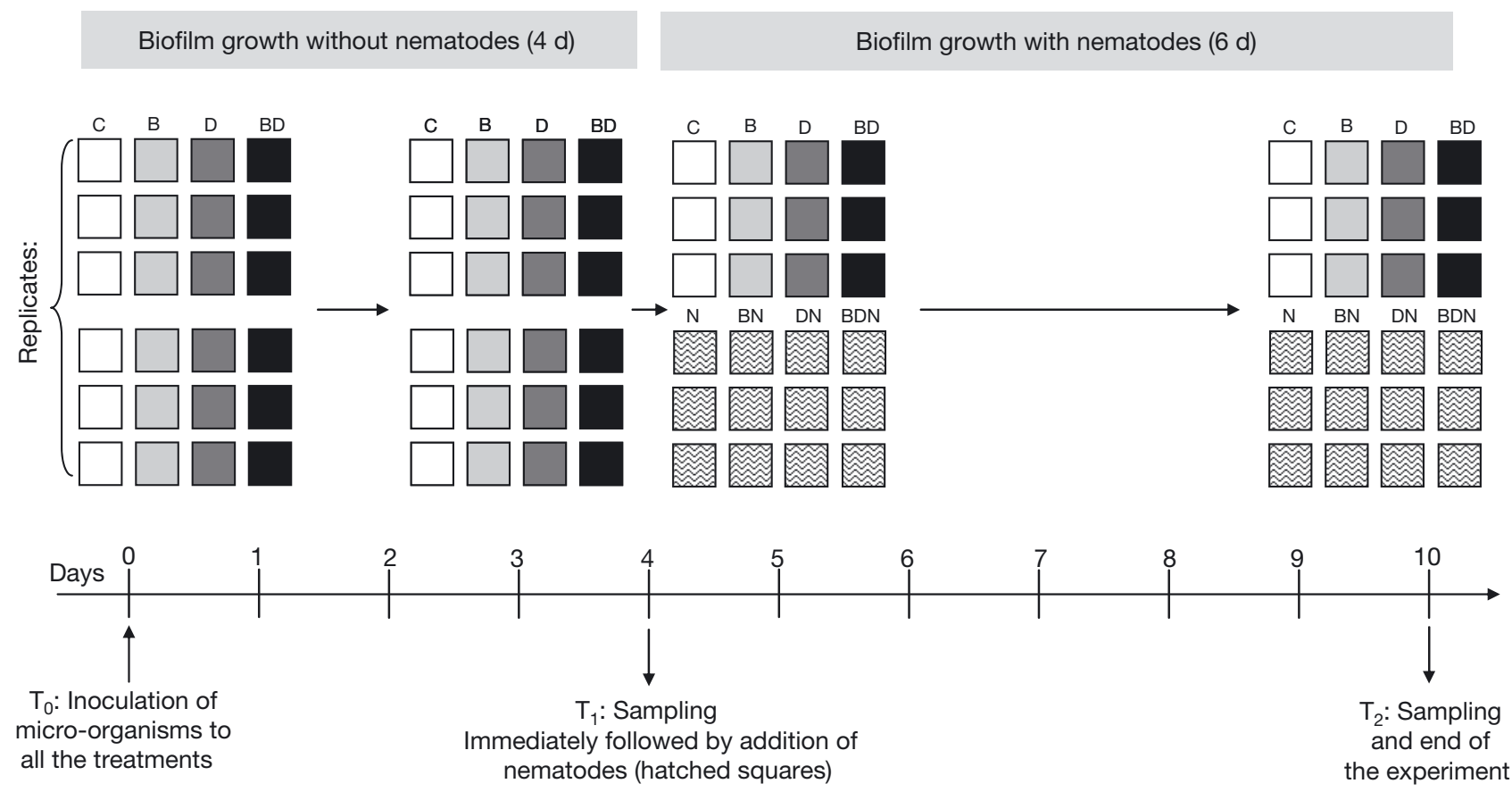

Fig. 1. Overview of the experimental protocol. Treatment name refers to the first letter of the corresponding culture(s) inoculated: bacteria (B), diatoms (D) and nematodes $(\mathrm{N})$, or $\mathrm{C}$ for the control. At the beginning of the experiment $\left(\mathrm{T}_{0}\right)$ microorganisms (bacteria and diatoms) were inoculated separately and together (4 treatments, 6 replicates per treatment). The biofilm was grown over $4 \mathrm{~d}$ and 4 cores were sampled in each box ( $\mathrm{T}_{1}$ : one each for the EPS, bacterial cell number, lipids and chl a). Immediately after sampling, bacterivorous nematodes were added to half of the replicates (hatched squares) and the biofilm was grown for 6 additional days. Each box was then re-sampled as described above $\left(\mathrm{T}_{2}\right)$ 
Chlorophyll a (chl a). To estimate diatom biomass, sediment cores were directly mixed with $5 \mathrm{ml}$ of $90 \%$ acetone and incubated in the dark for $4 \mathrm{~h}$ to extract the photosynthetic pigments (Strickland \& Parsons 1972). The supernatant was carefully transferred to a sterile tube and chl a fluorescence was measured by fluorimetry (Yentsch \& Menzel 1963, Lorenzen 1966).

EPS concentration. All the cores were mixed with $2 \mathrm{ml}$ of distilled water for $1.5 \mathrm{~h}$ with a tube roller (Denley Instruments). The sample was then centrifuged $(6030 \times g, 10 \mathrm{~min})$ and the supernatant containing the water-extractable fraction was sub-sampled. Carbohydrate and protein analyses were performed following the phenol assay protocol (Dubois et al. 1956) and the modified Lowry procedure (Raunkjaer et al. 1994), respectively. For colloidal carbohydrate analyses, $200 \mathrm{\mu l} \mathrm{phenol} \mathrm{(5 \% )} \mathrm{and} 1 \mathrm{ml}$ sulphuric acid (98\%) were added to $200 \mu \mathrm{l}$ of the subsamples. They were then incubated for $35 \mathrm{~min}$ at $30^{\circ} \mathrm{C}$ and the carbohydrate concentration was measured with a spectrophotometer at $488 \mathrm{~nm}$ (Milton Roy Spectronic Genesys 2). For colloidal protein analyses, $250 \mu \mathrm{l}$ subsamples were incubated for $15 \mathrm{~min}$ at $30^{\circ} \mathrm{C}$ with $250 \mu \mathrm{l}$ of $2 \%$ sodium dodecyl sulphate salt (SDS) and $700 \mu \mathrm{l}$ of a chemical cocktail prepared as described in Dubois et al. (1956). The subsamples were then incubated again for $45 \mathrm{~min}$ at $30^{\circ} \mathrm{C}$ with $100 \mu \mathrm{l}$ of Folin reagent (diluted with distilled water 5:6 v/v). The protein concentration was measured by spectrophotometry at $750 \mathrm{~nm}$. Calibration curves were prepared using glucose and bovine serum albumin (BSA) as standards for carbohydrates and proteins, respectively.

Total lipid concentration. Lipids of all the sediment cores were extracted with a chloroform/methanol cocktail (1:2 v/v) according to Bligh \& Dyer (1959). The supernatant containing the extraction cocktail and the lipids was carefully removed and evaporated with nitrogen. Lipids were thus released at the bottom of the tube and their weight measured directly using a microbalance.

Statistics. As the majority of our treatments did not pass the Kolmogorov-Smirnov normality test and Bartlett test for homogeneity of variance, the non-parametric Kruskal-Wallis test of variance was used. When the treatments were significantly different, the test was followed by the non-parametric post-hoc StudentNewman-Keuls (SNK) test for multiple comparisons. For bacterial abundance and chl $a$, a baseline was calculated by averaging the results of the controls and all the treatments which had not originally been inoculated with bacteria and chl $a$, respectively, and which had been supplemented with antibiotics (i.e. were not supposed to contain either bacteria or chl a). The Wilcoxon-Mann-Whitney test was then used to compare the remaining treatments to the baselines.
The correlation between colloidal EPS components was tested with a Spearman's rank correlation coefficient. The relationship between these parameters was investigated with a simple linear regression.

A distance matrix was calculated for the first and the second sampling dates using EPS concentrations, bacterial abundance and chl a biomass of each treatment (Primer $5^{\circledR}$, Primer-E). A normalized Euclidean distance was calculated between the treatments, and the resulting similarity matrix was plotted (non-metric multidimensional scaling, NMDS) using 99 iterations. Treatments were grouped according to their complexity and were allocated a number ranging between 0 and 3 according to the number of organism groups involved in the experiment (i.e. diatoms as primary producers, nematodes as consumers and bacteria as decomposers). An analysis of similarities (ANOSIM) was performed (2000 permutations) to test for significant differences between different levels of treatment complexity.

\section{RESULTS}

\section{Microbial abundance and biomass}

For the first sampling date $\left(T_{1}\right)$, bacterial abundance in treatment B was not significantly different from the baseline (Mann-Whitney test, $U=28.00, \mathrm{p}>0.05$ ) (Fig. 2a). The difference was significant for treatment BD (Mann-Whitney test, $U=5.00, \mathrm{p}<0.01$ ). For the second sampling date $\left(\mathrm{T}_{2}\right)$, bacterial abundance was between $2 \times 10^{6}$ and $24 \times 10^{6}$ cells cm${ }^{-2}$ depending on the treatment considered (Fig. 2b), which is lower than natural bacterial abundances of intertidal mud- and sandflats (i.e. typically about $10^{9}$ cells cm${ }^{-2}$; Epstein et al. 1997, Goñi-Urriza et al. 1999, Böttcher et al. 2000, Danovaro et al. 2001). Bacterial abundance was relatively stable between $T_{1}$ and $T_{2}$ in treatments $C, B, D$ and $\mathrm{BD}$, and was highest in treatments $\mathrm{BN}$ and $\mathrm{BDN}$ at $T_{2}$. At $T_{2}$, bacterial abundance in treatment $B$ was not significantly different from the baseline (Mann-Whitney test, $U=22.00, \mathrm{p}>0.05$ ). The difference was significant for treatments BD, BN and BDN (Mann-Whitney test, all $\mathrm{p}<0.01$ ) (Fig. 2b).

At $\mathrm{T}_{1}$, chl a concentrations in treatments $\mathrm{D}$ and $\mathrm{BD}$ were significantly different from the baseline (MannWhitney test, $\mathrm{p}<0.001$ and $\mathrm{p}<0.01$, respectively) (Fig. 2c). At $\mathrm{T}_{2}$, Chl a ranged from 0.001 to $0.007 \mu \mathrm{g}$ $\mathrm{cm}^{-2}$ depending on the treatment considered (Fig. 2d), which is lower than chlorophyll concentrations of natural intertidal mud- and sandflats (de Jonge \& Colijn 1994, Barranguet et al. 1997, Paterson \& Hagerthey 2001). Chl a concentration decreased slightly from the first to the last sampling in treat- 

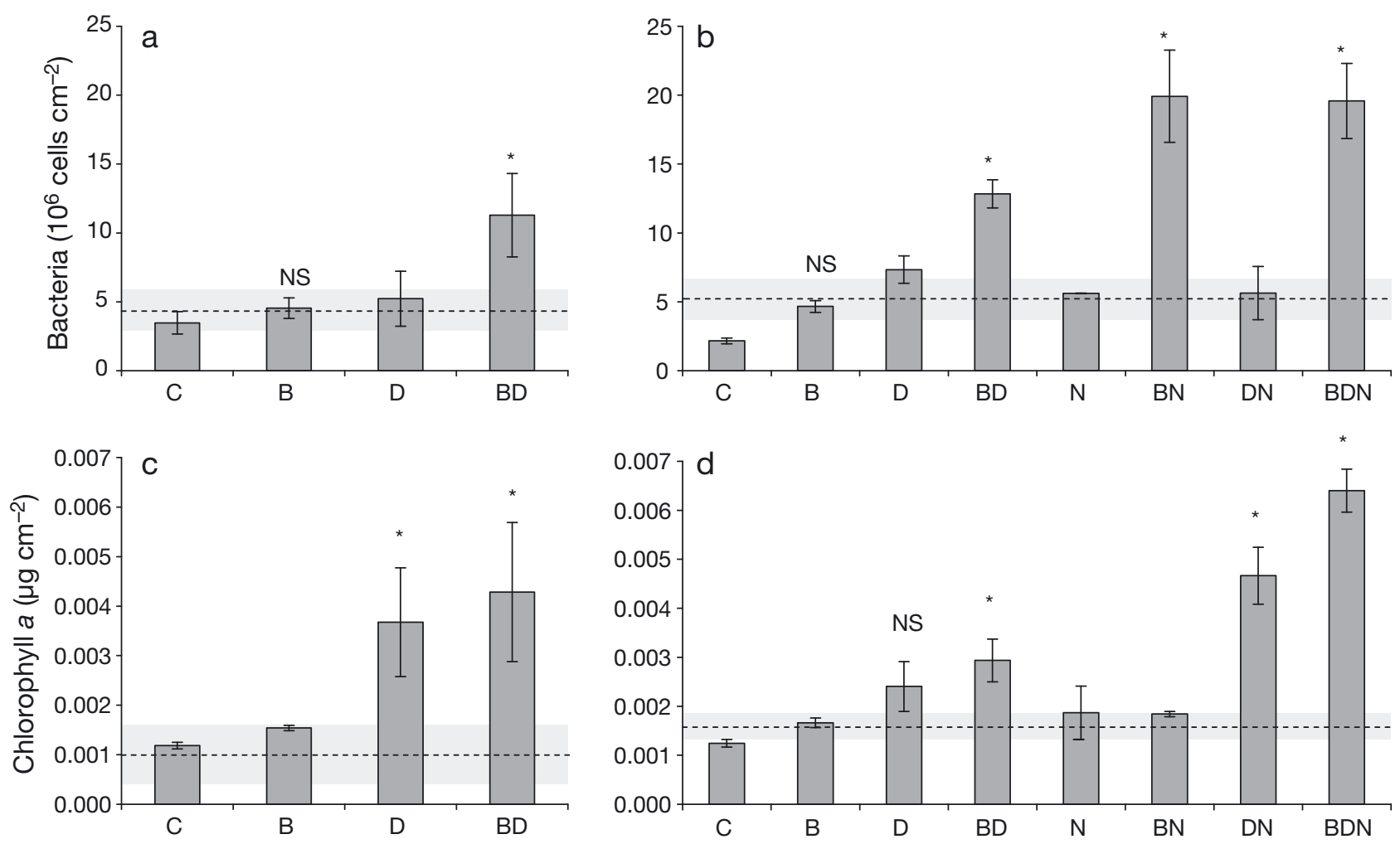

Fig. 2. Bacterial cell abundance and chl a concentration in superficial sediments for $(a, c)$ the first and (b,d) second sampling dates (mean $\pm \mathrm{SE})$. The dashed lines correspond to the average ( $\pm 95 \%$ confidence interval represented by the grey area) of all the treatments which were not originally inoculated with bacteria or diatoms (e.g. the dashed line in (b) was calculated with treatments $\mathrm{C}, \mathrm{D}, \mathrm{N}$ and $\mathrm{DN}$ ). The differences between the dashed line and the remaining treatments was tested (NS: not significant at $\mathrm{p}<0.05{ }^{*}$ : significant difference). See Fig. 1 for treatment abbreviations

ments $\mathrm{D}$ and $\mathrm{BD}$, and was highest in treatments $\mathrm{DN}$ and $\mathrm{BDN}$ at $\mathrm{T}_{2}$. Chl $a$ in treatment $\mathrm{D}$ was not significantly different from the baseline at $\mathrm{T}_{2}$ (MannWhitney test, $U=5.50, \mathrm{p}>0.05)$. The difference was significant for treatments BD, DN and BDN (MannWhitney test, all $\mathrm{p}<0.01$ ) (Fig. 2d).

\section{Colloidal EPS}

At $T_{1}$, colloidal carbohydrate concentrations of all the treatments were significantly different from the control, with treatment BD displaying the highest average concentration (Kruskal-Wallis, $H=13.18$, df $=3$, p < 0.01, followed by a SNK test) (Fig. 3a). At $T_{2}$, the carbohydrate concentrations of all the replicates of the control were below the detection limit. Thus, the carbohydrate concentration of the control group was set to zero and the concentrations of all the other treatments were considered significantly higher since they always exceeded 0. Treatment BDN displayed the highest concentrations (Kruskal-Wallis, $H=12.71$, df $=6, \mathrm{p}<$ 0.05, followed by a SNK test) (Fig. 3b).
Treatment BD displayed the highest average protein concentration at $\mathrm{T}_{1}$ (Kruskal-Wallis, $H=10.17$, $\mathrm{df}=3, \mathrm{p}<0.05$, followed by a SNK test) (Fig. 3c). At $\mathrm{T}_{2}$, the colloidal protein concentrations were significantly different from the control, and treatment BDN again displayed the highest concentration (KruskalWallis, $H=18.51$, df $=7, \mathrm{p}<0.01$, followed by a SNK test) (Fig. 3d).

For the first and the second sampling dates, colloidal carbohydrates and proteins were always significantly correlated (Spearman's correlation coefficient $\rho=0.57$ and 0.66, $\mathrm{p}<0.01$ and $\mathrm{p}<0.001$, respectively). For each sampling date, colloidal carbohydrates and proteins were significantly linearly related (Fig. 4).

\section{Total lipids}

For the first (Fig. 5a) and the second (Fig. 5b) sampling dates, total lipid concentrations of all the treatments were not significantly different $\left(\mathrm{T}_{1}\right.$ : KruskalWallis, $H=1.19, \mathrm{df}=3, \mathrm{p}>0.05, \mathrm{~T}_{2}$ : Kruskal-Wallis, $H=$ 1.19, df $=3, \mathrm{p}>0.05$ ). 

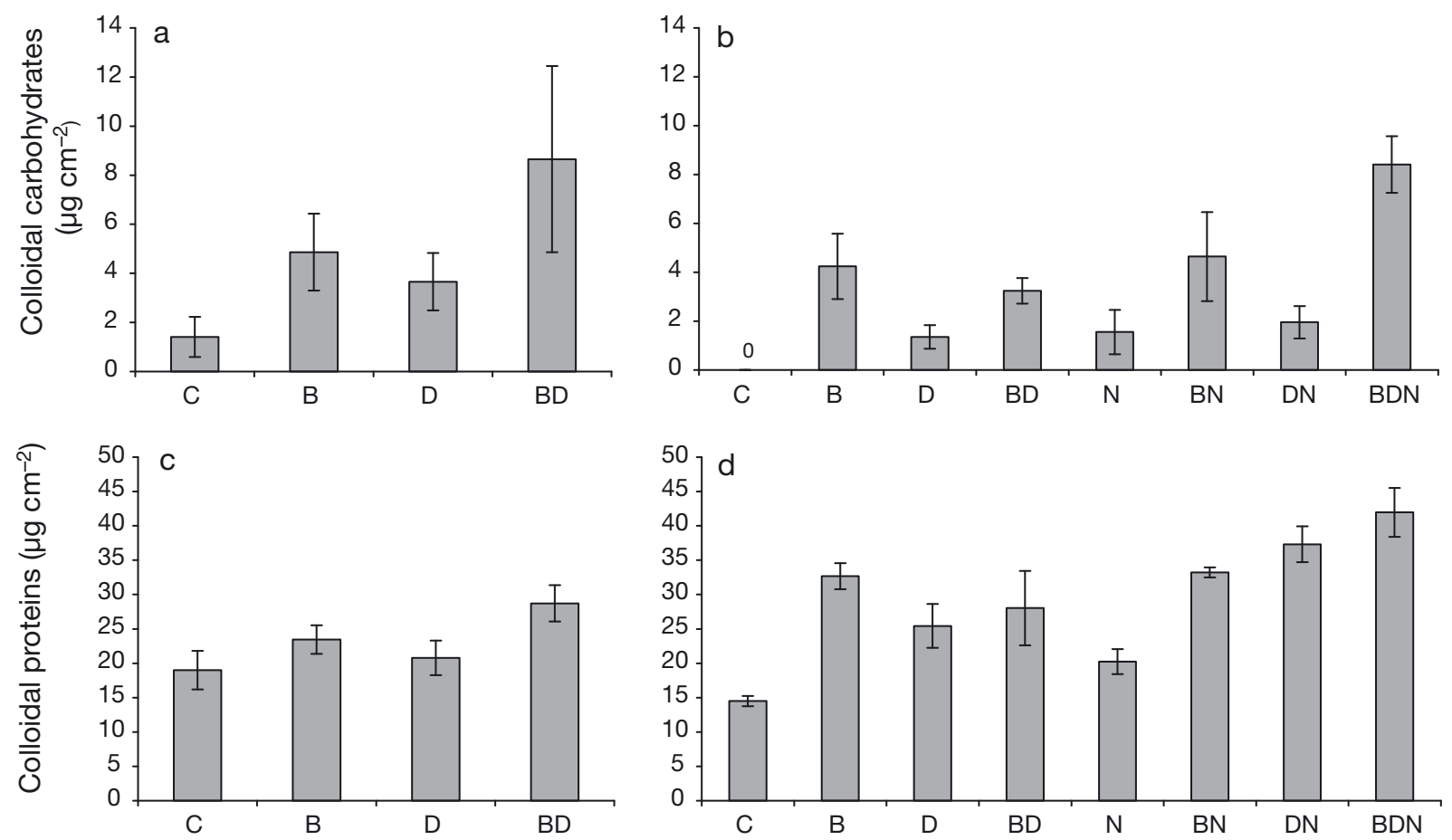

Fig. 3. Water-extractable carbohydrates and proteins in superficial sediments for $(\mathrm{a}, \mathrm{c})$ the first and $(\mathrm{b}, \mathrm{d})$ second sampling dates (mean \pm SE). See Fig. 1 for treatment abbreviations

\section{Treatment complexity}

At $\mathrm{T}_{1}, 3$ groups, corresponding to 3 different levels of complexity (i.e. 0, 1 and 2 organism groups), were revealed by the NMDS (global $R=0.40, \mathrm{p}<0.0001$ ) (Fig. 6a). All differences between pairs of groups were significant (all $R>0.5, \mathrm{p}<0.001$ ), except between groups 0 and $1(R=0.1, \mathrm{p}>0.05)$. The similarities between the different groups were mainly explained by an EPS gradient with highest EPS concentrations at the right end of the graph, corresponding to treatments involving 2 types of organisms.

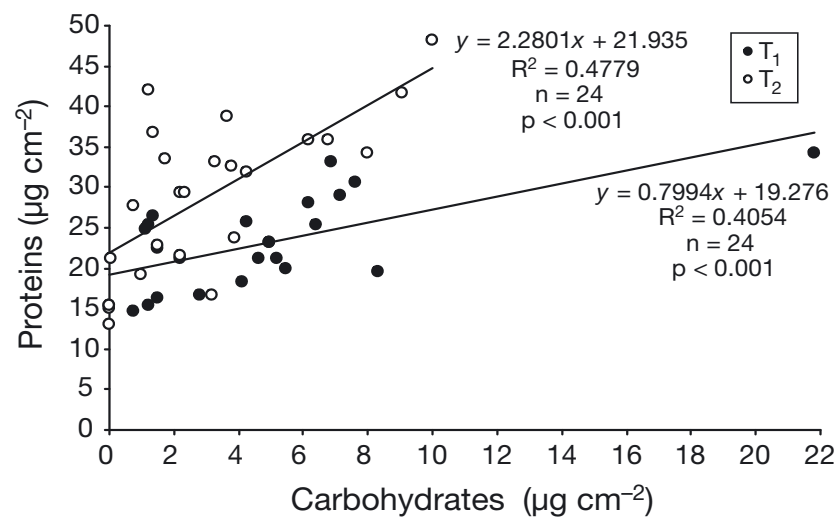

Fig. 4. Simple linear regressions between colloidal proteins and carbohydrates for the first $\left(T_{1}\right)$ and second $\left(T_{2}\right)$ sampling dates. The coefficient of determination $\left(\mathrm{R}^{2}\right)$, the number of values (n) and the $\mathrm{p}$-value are indicated
At $\mathrm{T}_{2}, 4$ groups, corresponding to 4 different levels of complexity (i.e. 0, 1, 2 and 3 types of organisms) were revealed by the NMDS (global $R=0.59, \mathrm{p}<0.0001$ ) (Fig. 6b). It was not possible to test for significant differences between groups 0 and 3 due to a limited number of replicates. All other pairwise comparisons were significant (all $R>0.5, \mathrm{p}<0.001$ ) except between groups 0 and $1(R=0.31, \mathrm{p}>0.05)$. As for $\mathrm{T}_{1}$, the protein and carbohydrate gradient explained the distribution of the different groups with highest concentrations at the right end of the graph, corresponding to the treatments involving bacteria, diatoms and nematodes.

\section{DISCUSSION}

\section{Biofilm development prior to nematode inoculation}

During the first $4 \mathrm{~d}$ of the experiment, prior to inoculation of nematodes in any treatment, bacteria and diatoms produced relatively low amounts of colloidal EPS $\left(\mathrm{T}_{1}\right.$ : Fig. 3a,c). The production of such compounds is relatively variable in natural environments and depends strongly on the physiological state of the cells and the environmental conditions (Decho 1990). Virtually no culture medium was added to our experiments so that the different treatments were probably nutrient limited. Consequently, bacteria and diatoms did not produce exopolymers and their abundance and bio- 

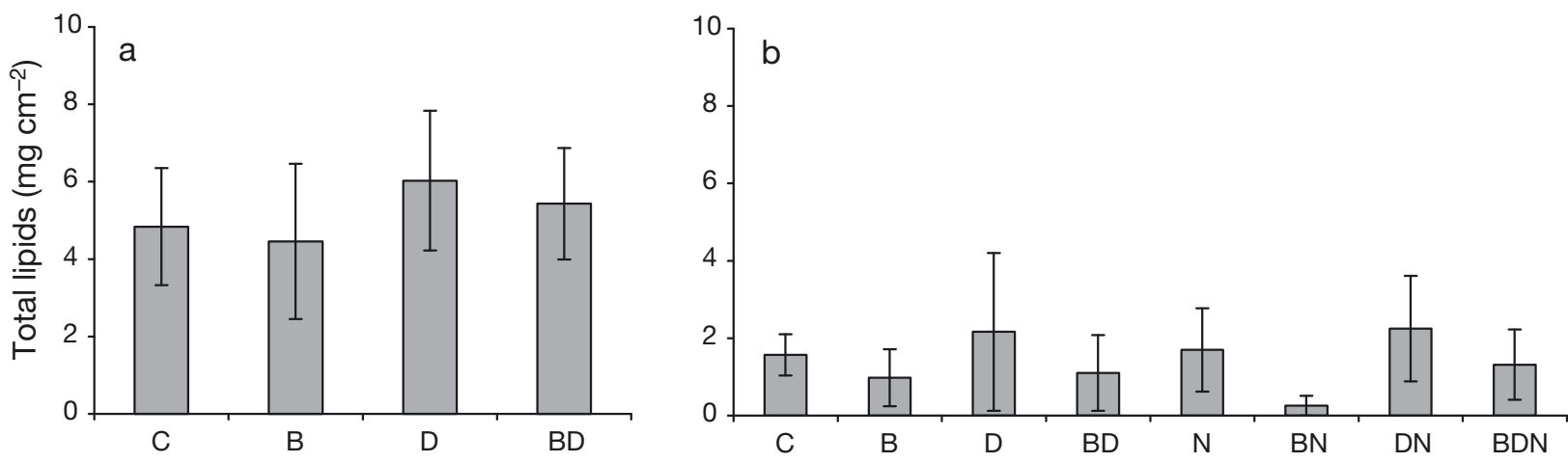

Fig. 5. Total lipids in superficial sediments for (a) the first and (b) second sampling dates (mean \pm SE). See Fig. 1 for treatment abbreviations

mass remained relatively low compared to natural sediments under similar environmental conditions. In natural sediments, nutrient limitation often results in an increase of bound EPS (which are adsorbed onto sediment particles) at the expense of the soluble exopolymers (Orvain et al. 2003). Since we measured only the water-extractable (soluble) fraction, we may have missed a possible increase in bound EPS in our treatments, particularly in treatment $\mathrm{D}$ as a result of the diatom biomass increase (Fig. 2c). In addition, even though we applied antibiotics sparingly in each treatment (i.e. we inoculated them only at the beginning of the experiment and we avoided chloroamphenicol when diatoms were grown alone) we cannot ignore that it may have impacted the production of microalgal polymers in the corresponding treatments.

When bacteria and diatoms were grown together (treatment BD), they produced much more EPS than when grown separately. This treatment consistently showed the highest EPS concentrations and the highest microbial abundance/biomass after $4 \mathrm{~d}$, suggesting an additive effect (Figs. 2a,c \& 3a,c). Soft-sediment biofilms are often colonized by a large diversity of microbes forming assemblages characterized by complex microbial interactions (Laanbroek et al. 1982), and the co-occurrence of diatoms and bacteria often leads to an increase in biomass and EPS secretion (Bruckner et al. 2008). This was observed in previous experiments and was associated with an increase in sediment stability (Gerbersdorf et al. 2008). In our experiment, the development of a bacterial biofilm probably stimulated the growth of benthic microalgae mainly through nutrient enrichment (Fukami et al. 1997). In addition, bacteria may have benefited from microalgal exudates which enhanced the remineralisation rate. The breakdown of carbohydrate molecules probably represented a significant remineralisation pathway in our experiment. Indeed, the increase in EPS concentration in treatment BD was more pronounced for carbohydrates than for proteins. Carbohydrates are generally largely secreted
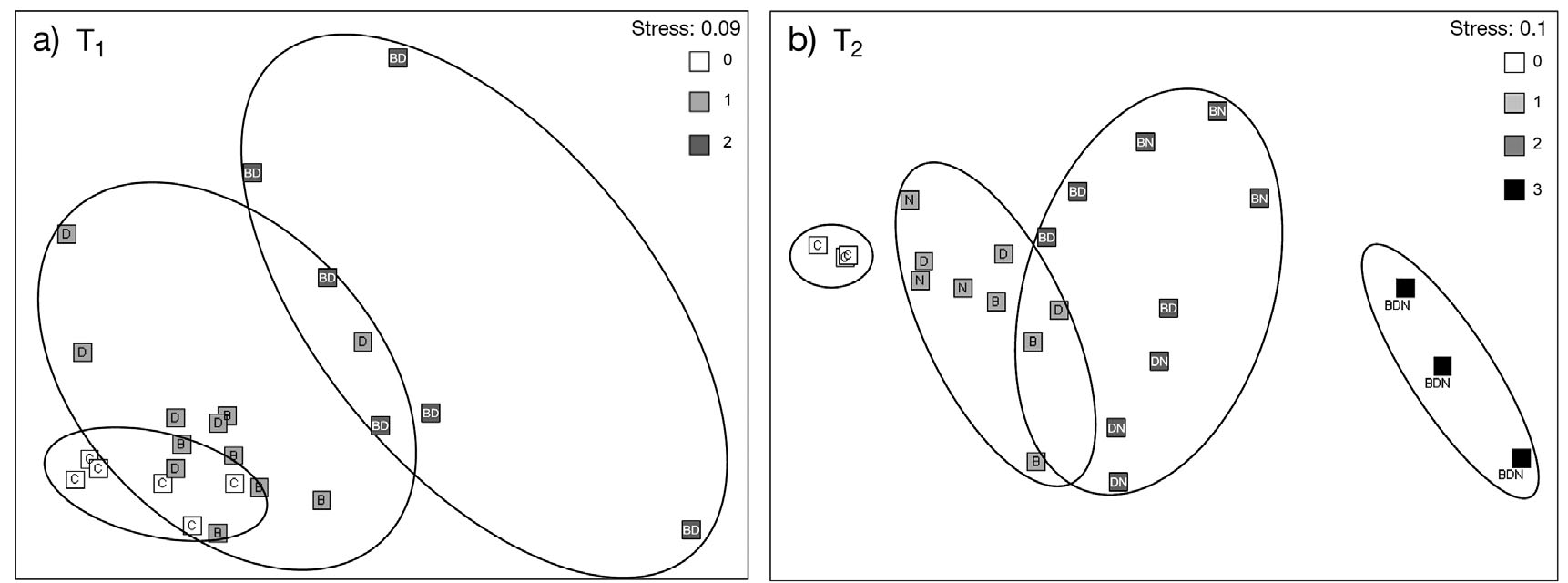

Fig. 6. Non-metric multidimensional scaling (NMDS) using bacterial cell number, chl $a$, proteins and carbohydrates of (a) the first $\left(\mathrm{T}_{1}\right)$ and $(\mathrm{b})$ second $\left(\mathrm{T}_{2}\right)$ sampling dates. Treatments were grouped according to the mixture complexity. The number of trophic levels ( 0 to 3 ) involved in the treatments is indicated. See Fig. 1 for abbreviations 
by benthic microalgae (Stal 2010) and also dominate Navicula incerta cell composition over proteins (13\% vs. $2 \%$, respectively, Affan et al. 2007). Thus, the microbial loop in our treatments was probably mainly sustained by the exoglycosidase activity of the bacterial assemblage.

\section{Effect of bacterivorous nematodes on microbial growth and exopolymer production}

To our knowledge, there have been no quantitative reports of effects of meiofauna on microbial exopolymer production. The selected nematodes, Diplolaimelloides meyli and $D$. oschei, are 2 congeneric species which typically occupy several types of decomposing macrophyte detritus in estuarine intertidal areas (dos Santos et al. 2008), where they feed largely but not exclusively on bacteria (Moens \& Vincx 1997). These and other monhysterid nematodes have been shown to affect bacterial activity and detritus decomposition rates (De Mesel et al. 2006). Even at relatively low densities, they can also significantly impact bacterial community composition in a very species-specific way. This may result from differential food preferences (De Mesel et al. 2004) and/or from more indirect interactions (Moens et al. 2005).

During locomotion, many nematodes secrete significant amounts of mucus, which may agglutinate sediment particles (Gerlach 1978, Riemann \& Schrage 1978), fix eggs to substrata (T. Moens pers. obs.), or facilitate settlement of specific strains of bacteria (Moens et al. 2005) and life stages of microalgae (Warwick 1981). It has been suggested that these mucus tracks serve to trap bacteria which will then be grazed upon by the nematodes (mucus-trap hypothesis, Riemann \& Schrage 1978, Moens et al. 2005), but this hypothesis has not been confirmed. Nematode mucus secretions contain a substantial amount of acid mucopolysaccharides (Riemann \& Schrage 1978). However, when grown alone (treatment $\mathrm{N}$ ), nematodes in our experiment did not produce high amounts of colloidal EPS (Fig. 3c,d). This could be due to the low abundances of nematodes, or to the absence of bacterial food in treatment $\mathrm{N}$, which may well have negatively impacted nematode activity and movement.

The co-occurrence of bacteria and nematodes (treatment BN) significantly increased the EPS production compared to treatment $\mathrm{N}$, but not compared to treatment B (Fig. 3c,d). Bacterial abundance, however, was drastically higher in $\mathrm{BN}$ than in B. Bacterial grazing by nematodes was clearly not high enough to negatively impact bacterial proliferation. Such top-down controls on bacterial abundance probably only occur at high abundances of nematodes with high grazing rates (De
Mesel et al. 2006), and not at the relatively low nematode densities of our experiment. A stimulatory effect of nematodes on microbial abundance may result from (1) microbioturbation, improving oxygen and nutrient distribution in sediments (Alkemade et al. 1992, Aller \& Aller 1992), (2) fragmentation of organic matter particles (Coull 1999), (3) moderate grazing, preventing bacteria from rapidly reaching carrying capacity, and (4) excretion of nitrogen-rich compounds which stimulate microbial growth (Ingham et al. 1985, Ferris et al. 1998). The first and last explanations appear most plausible for our experiment. Nematode movement may have facilitated oxygen penetration into the sediment. At the same time, bacteria-feeding nematodes generally take up more nitrogen than necessary for their growth (Ferris et al. 1997, 1998). This excess nitrogen is usually excreted as ammonium and may relieve nutrient limitation for bacteria as well as for diatoms.

As for treatment BN, the simultaneous presence of diatoms and nematodes (treatment DN) increased the EPS production compared to treatment N (Fig. 3c,d), as well as protein and chl a concentrations compared to treatment D. A possible explanation is that the aforementioned nitrogen excretion by nematodes provided enough nutrients to stimulate diatom growth and protein production.

In the presence of nematodes, the additive effect observed between bacteria and diatoms at the first sampling date $\left(T_{1}\right)$ was even more pronounced. For instance, the carbohydrate concentration increased from the control to BDN (e.g. carbohydrate content in $\mathrm{C}<\mathrm{D}$ $<\mathrm{BD}<\mathrm{BDN}$, Fig. 3b). As mentioned before, nematodes probably stimulated bacterial growth and subsequent mineralization/nutrient generation, which may in return have stimulated microagal proliferation. In addition, as hypothesised by Riemann \& Helmke (2002), the metabolic activities of mucus-secreting nematodes and the associated bacteria may have complemented each other in this treatment. Indeed, these authors demonstrated that several marine nematode families release enzymes which contribute to the complex microbial exo-enzymatic pool by solely allowing the cleavage of refractory polysaccharides containing $\beta$-glycosidic bonds. In return, these authors propose that nematodes rely mostly on the exoproteolytic activity of co-occurring heterotrophic bacteria to sustain their nitrogen needs. In our study, nematodes in treatment BDN probably obtained most of their nitrogen from the ingestion and digestion of bacterial cells. In addition it is possible that, conversely to other treatments, the presence of bacteria helped to fulfill nematode and diatom nitrogen needs by breaking down proteins. This could explain why treatment BDN, which assembled all the studied organisms, displayed the highest polymer and biomass contents. 


\section{The complexity of micro-benthic assemblages as a potential bio-stabilisation force in marine sediments}

Our study provides an intriguing indication that the assemblage complexity rather than the presence of any particular organism impacts strongly on biofilm structure, both in terms of microbial abundance/biomass and EPS contents (Fig. 6). With increasing complexity, the number of trophic links and interactions also increased in our treatments. Caution is of course due when extrapolating this conclusion to natural habitats, since the community used in this study was far simpler than in any natural soft sediments habitat, both in terms of diversity and biomass. For instance, we used 2 nematode species belonging to one functional group in our assemblages, while natural meiofaunal communities at local scales $\left(10 \mathrm{~cm}^{2}\right)$ can display from a dozen to more than 100 species and several functional groups of nematodes (Warwick 1975, Heip et al. 1985). We also inoculated only one diatom species, compared to the several dozen typically inhabiting most intertidal sand- and mudflats (e.g. Ribeiro et al. 2003). Thus, further experiments involving considerably higher levels of community complexity are required before the present results may be extrapolated to natural conditions. However, it is known that increasing the diversity of trophic links and energy pathways in any particular community is a way to improve the ability of that community to withstand external perturbations (Paine 1969). In that context, it is important that both vertical and horizontal diversity (i.e. diversity across and within trophic levels, respectively) are maximized to maintain all the functions of a given ecosystem (Duffy et al. 2007). In addition, it has been shown that sediment stability (i.e. in terms of cohesive strength and resistance of the sediments to erosion) is often correlated to the EPS content (Gerbersdorf et al. 2008). Thus, these results raise interesting concerns about the bio-stabilisation ability of micro- and meiobenthic assemblages and how this is driven by their own complexity and trophic interactions. Further experiments including multiple levels of diversity within and across benthic compartments are thus required to test this hypothesis.

Acknowledgements. The authors thank A. Andouche and staff of the "Evolution and functions of the nervous and neuroendocrine system' research group of the Museum of Natural History, Paris, for providing access to the autoclave. We are also grateful to J. M. Mortillaro and T. Meziane for helping with the total lipid measurements and G. Schaal for the sampling of the intertidal mud in the Dourduff river. A.R. and T.M. received support from the Flemish Foundation for Scientific Research (FWO) and from Ghent University through projects 3G019209W and BOF 09/24J/148. H.V.L. was supported by the EU Marie Curie Research Training Network (RTN-CT 2006-035695), Project KEYBIOEFFECT.

\section{LITERATURE CITED}

Affan A, Karawita R, Jeon YJ, Lee JB (2007) Growth characteristics and antioxidant properties of the benthic diatom Navicula incerta (Bacillariophyceae) from Jeju Island, Korea. J Phycol 43:823-832

Alkemade R, Wielemaker A, de Jong SA, Sandee AJJ (1992) Experimental evidence for the role of bioturbation by the marine nematode Diplolaimella dievengatensis in stimulating the mineralization of Spartina anglica detritus. Mar Ecol Prog Ser 90:149-155

Aller RC, Aller JY (1992) Meiofauna and solute transport in marine muds. Limnol Oceanogr 37:1018-1033

> Barranguet C, Herman PMJ, Sinke JJ (1997) Microphytobenthos biomass and community composition studied by pigment biomarkers: importance and fate in the carbon cycle of tidal flat. J Sea Res 38:59-70

Berland BR, Maestrini SY (1969) Action de quelques antibiotiques sur le développement de cinq diatomées en culture. J Exp Mar Biol Ecol 3:62-75

Bligh EG, Dyer WJ (1959) A rapid method of total lipid extraction and purification. Can J Biochem Physiol 37:911-917

> Böttcher ME, Hespenheide B, Llobet-Brossa E, Beardsley C and others (2000) The biogeochemistry, stable isotope geochemistry, and microbial community structure of a temperate intertidal mudflat: an integrated study. Cont Shelf Res 20:1749-1769

Bruckner CG, Bahulikar R, Rahalkar M, Schink B, Kroth PG (2008) Bacteria associated with benthic diatoms from Lake Constance: phylogeny and influences on diatom growth and secretion of extracellular polymeric substances. Appl Environ Microbiol 74:7740-7749

Chapman MG, Tolhurst TJ (2007) Relationships between benthic macrofauna and biogeochemical properties of sediments at different spatial scales and among different habitats in mangrove forests. J Exp Mar Biol Ecol 343: 96-109

> Coull BC (1999) Role of meiofauna in estuarine soft-bottom habitats. Aust J Ecol 24:327-343

Dade WB, Nowell ARM, Jumars PA (1992) Predicting erosion resistance of muds. Mar Geol 105:285-297

Danovaro R, Armeni M, Dell'Anno A, Fabiano M and others (2001) Small-scale distribution of bacteria, enzymatic activities and organic matter in coastal sediments. Microb Ecol 42:177-185

de Deckere EMGT, Tolhurst TJ, de Brouwer JFC (2001) Destabilization of cohesive intertidal sediments by infauna. Estuar Coast Shelf Sci 53:665-669

de Jonge VN, Colijn F (1994) Dynamics of microphytobenthos biomass in the Ems estuary. Mar Ecol Prog Ser 104: 185-196

> De Mesel I, Derycke S, Moens T, Van der Gucht K, Vincx M, Swings J (2004) Top-down impact of bacterivorous nematodes on the bacterial community structure: a microcosm study. Environ Microbiol 6:733-744

> De Mesel I, Derycke S, Swings J, Vincx M, Moens T (2006) Role of nematodes in decomposition processes: Does within-trophic group diversity matter? Mar Ecol Prog Ser 321:157-166

Decho AW (1990) Microbial exopolymer secretions in ocean environments: their role(s) in food webs and marine processes. Oceanogr Mar Biol Annu Rev 28:73-153

dos Santos GAP, Derycke S, Fonsêca-Genevois VG, Coelho LCBB, Correia MTS, Moens T (2008) Differential effects of food availability on population growth and fitness of three species of estuarine, bacterial-feeding nematodes. J Exp Mar Biol Ecol 355:27-40 
Dubois M, Gilles KA, Hamilton JK, Rebers PA, Smith F (1956) Colorimetric method for determination of sugars and related substances. Anal Chem 28:350-356

Duffy JE, Cardinale BJ, France KE, McIntyre PB, Thébault E, Loreau M (2007) The functional role of biodiversity in ecosystems: incorporating trophic complexity. Ecol Lett 10:522-538

Epstein SS, Alexander D, Cosman K, Dompé A and others (1997) Enumeration of sandy sediment bacteria: Are the counts quantitative or relative? Mar Ecol Prog Ser 151: $11-16$

Ferris H, Venette RC, Lau SS (1997) Population energetics of bacterial-feeding nematodes: carbon and nitrogen budgets. Soil Biol Biochem 29:1183-1194

Ferris H, Venette RC, van der Meulen HR, Lau SS (1998) Nitrogen mineralization by bacterial-feeding nematodes: verification and measurement. Plant Soil 203:159-171

Fukami K, Nishijima T, Ishida Y (1997) Stimulative and inhibitory effects of bacteria on the growth of microalgae. Hydrobiologia 358:185-191

> Gerbersdorf SU, Manz W, Paterson DM (2008) The engineering potential of natural benthic bacterial assemblages in terms of the erosion resistance of sediments. FEMS Microbiol Ecol 66:282-294

> Gerlach SA (1978) Food-chain relationships in subtidal silty sand marine sediments and the role of meiofauna in stimulating bacterial productivity. Oecologia 33:55-69

- Goñi-Urriza M, de Montaudouin X, Guyoneaud R, Bachelet G, de Wit R (1999) Effect of macrofaunal bioturbation on bacterial distribution in marine sandy sediments, with special reference to sulphuroxidising bacteria. J Sea Res 41:269-279

Hagerthey SE, Defew EC, Paterson DM (2002) Influence of Corophium volutator and Hydrobia ulvae on intertidal benthic diatom assemblages under different nutrient and temperature regimes. Mar Ecol Prog Ser 245:47-59

> Hansen K, Kristensen E (1997) Impact of macrofaunal recolonization on benthic metabolism and nutrient fluxes in a shallow marine sediment previously overgrown with macroalgal mats. Estuar Coast Shelf Sci 45:613-628

Heip C, Vincx M, Vranken G (1985) The ecology of marine nematodes. Oceanogr Mar Biol Annu Rev 23:399-489

Ingham RE, Trofymow JA, Ingham ER, Coleman DC (1985) Interactions of bacteria, fungi, and their nematode grazers: effects on nutrient cycling and plant-growth. Ecol Monogr 55:119-140

Laanbroek HJ, Veldkamp H, Postgate JR, Lynch JM, Roux NL (1982) Microbial interactions in sediment communities [and discussion]. Philos Trans R Soc Lond B Biol Sci 297: $533-550$

Lee JJ (1993) General techniques for the isolation and culture of marine protists from estuarine, littoral, and sublittoral waters. In: Kemp PF, Sherr FB, Sherr EB, Cole JJ (eds) Handbook of methods in aquatic microbial ecology. Lewis Publishers, Boca Raton, FL

Lorenzen CJ (1966) A method for the continuous measurement of in vivo chlorophyll concentration. Deep-Sea Res I 13:223-227

MacIntyre HL, Geider RJ, Miller DC (1996) Microphytobenthos: the ecological role of the 'secret garden' of unvegetated, shallow-water marine habitats. I. Distribution, abundance and primary production. Estuaries 19:186-201

Miller CD, Geider RJ, MacIntyre HL (1996) Microphytobenthos: the ecological role of the 'secret garden' of unvegetated, shallow-water marine habitats. II. Role in sediment stability and shallow-water food webs. Estuaries 19: 202-212

Moens T, Vincx M (1997) Observations on the feeding ecology of estuarine nematodes. J Mar Biol Assoc UK 77: 211-227

Moens T, Vincx M (1998) On the cultivation of free-living marine and estuarine nematodes. Helgol Meersunters 52: $115-139$

Moens T, dos Santos GAP, Thompson F, Swings J, FonsecaGenevois V, Vincx M, De Mesel I (2005) Do nematode mucus secretions affect bacterial growth? Aquat Microb Ecol 40:77-83

> Orvain F, Galois R, Barnard C, Sylvestre A, Blanchard G, Sauriau PG (2003) Carbohydrate production in relation to microphytobenthic biofilm development: an integrated approach in a tidal mesocosm. Microb Ecol 45:237-251

Paine RT (1969) A note on trophic complexity and community stability. Am Nat 103:91-93

Paterson DM, Hagerthey SE (2001) Microphytobenthos in contrasting coastal ecosystems: biology and dynamics. In: Reise K (ed) Ecological comparisons of sedimentary shores, Vol 151. Springer, Berlin, p 105-125

> Raunkjaer K, Hvitved-Jacobsen T, Nielsen PH (1994) Measurement of pools of protein, carbohydrate and lipid in domestic wastewater. Water Res 28:251-262

Ribeiro L, Brotas V, Mascarell G, Coute A (2003) Taxonomic survey of the microphytobenthic communities of two Tagus estuary mudflats. Acta Oecol Int J Ecol 24: S117-S123

> Riemann F, Helmke E (2002) Symbiotic relations of sedimentagglutinating nematodes and bacteria in detrital habitats: the enzyme-sharing concept. PSZN I: Mar Ecol 23:93-113

Riemann F, Schrage M (1978) The mucus-trap hypothesis on feeding of aquatic nematodes and implications for biodegradation and sediment texture. Oecologia 34:75-88

> Riera P, Richard P, Grémare A, Blanchard G (1996) Food source of intertidal nematodes in the Bay of MarennesOléron (France), as determined by dual stable isotope analysis. Mar Ecol Prog Ser 142:303-309

Smith DJ, Underwood GJC (1998) Exopolymer production by intertidal epipelic diatoms. Limnol Oceanogr 43: 1578-1591

Stal LJ (2010) Microphytobenthos as a biogeomorphological force in intertidal sediment stabilization. Ecol Eng 36: $236-245$

Strickland JDH, Parsons TR (1972) A practical handbook of seawater analysis. Bull Fish Res Bd Can 167

Sundbäck K, Miles A, Göransson E (2000) Nitrogen fluxes, denitrification and the role of microphytobenthos in microtidal shallow-water sediments: an annual study. Mar Ecol Prog Ser 200:59-76

Underwood GJC, Paterson DM, Parkes RJ (1995) The measurement of microbial carbohydrate exopolymers from intertidal sediments. Limnol Oceanogr 40:1243-1253

Warwick LN (1975) The biology of free-living nematodes. Oxford University Press, London

Warwick RM (1981) Survival strategies of meiofauna. In: Jones NV, Wolff WJ (eds) Feeding and survival strategies of estuarine organisms. Plenum Press, New York, NY, p 39-52

- Wotton RS (2004) The ubiquity and many roles of exopolymers (EPS) in aquatic systems. Sci Mar 68:13-21

Yentsch CS, Menzel DW (1963) A method for the determination of phytoplankton chlorophyll and phaeophytin by fluorescence. Deep-Sea Res 10:221-231 